\title{
Neurofilament Light Polypeptide
}

National Cancer Institute

\section{Source}

National Cancer Institute. Neurofilament Light Polypeptide. NCI Thesaurus. Code C88043.

Neurofilament light polypeptide (543 aa, $\sim 62 \mathrm{kDa}$ ) is encoded by the human NEFL gene.

This protein is involved in the modulation of neuronal structure. 